О. П. Волосовець, О. В. Виговська, С. П. Кривопустов, А. Я. Кузьменко, І. О. Логінова, О. Ф. Черній, О. В. Мозирська, В. Є. Хоменко, О. Л. Ковальчук, О. Л. Дзюба, Н. В. Грищенко, М. С. Острополець, О. О. Скварська, С. Д. Салтанова, О. В. Ковтун Національний медичний університет імені О. О. Богомольця, Київ

\title{
ДИСТАНЦІЙНЕ НАВЧАННЯ ЯК ІНФОРМАЦІЙНО-КОМУНІКАТИВНА ТЕХНОЛОГІЯ ДОДИПЛОМНОЇ ПІДГОТОВКИ ЛІКАРІВ 3 ПЕДІАТРІЇ В УМОВАХ СУЧАСНИХ ВИКЛИКІВ
}

\author{
O. P. Volosovets, O. V. Vyhovska, S. P. Kryvopustov, A. Ya. Kuzmenko, \\ I. O. Loginova, O. F. Cherny, O. V. Mozyrska, V. E. Khomenko, \\ O. L. Kovalchuk, O. L. Dzyuba, N. V. Gryshchenko, M. S. Ostropolets, \\ O. O. Skvarskaya, S. D. Saltanova, O. V. Kovtun \\ O. Bohomolets National Medical University, Kyiv

\section{DISTANCE LEARNING AS AN INFORMATION AND COMMUNICATIVE TECHNOLOGY OF THE UNDERGRADUATE TRAINING OF PEDIATRICIANS IN THE CONTEMPORARY CHALLENGE}

\begin{abstract}
Анотація. Для реалізації та адекватного віртуального забезпечення дистанційної освіти у Національному медичному університеті імені О. О. Богомольця використовується дистанційна освітня платформа NMU Neuron, що в нинішній ситуації може стати дієвою складовою освітнього процесу, маючи при цьому низку переваг. Воно не лише забезпечує навчання студента у найбільш зручному місці та часі, доступ до електронних баз знань, але й суттєво підвищує його активну роль у самому процесі самостійного навчання, зокрема й під час вимушеного внаслідок карантину, а від викладача вимагає вдосконалення викладання як за змістом, так і за його формою.

Основними видами занять за дистанційною формою навчання є традиційні форми освітньої підготовки: лекція, практичні заняття, семінар, лабораторні заняття, консультації та інші, що відповідають чинному законодавству.

У цілому, технології дистанційного навчання як комплекс сучасних освітніх технологій у системі вищої медичної освіти має постійно вдосконалюватися, зокрема шляхом використання сучасних освітніх платформ, якісного методичного наповнення веб-ресурсів, запровадження системи контролю якості дистанційного навчання, аби відповідати викликам часу.
\end{abstract}

Ключові слова: дистанційна освіта; педіатрія; додипломна підготовка.

Abstract. For the implementation and adequate virtual provision of distance education at O. Bohomolets National Medical University, the NMU Neuron distance educational platform is used, which in the current situation can become an effective component of the educational process, while having a number of advantages. It not only provides the student with the most convenient place and time, access to electronic knowledge bases, but also significantly enhances his/her active role in the self-study process, including during the quarantined process, and requires the teacher to improve the teaching in terms of content, and in its form.

The main types of distance learning courses are traditional forms of educational training: lectures, practical classes, seminars, labs, consultations and other relevant legislation.

In general, distance learning technologies as a complex of modern educational technologies in the higher medical education system should be constantly improved, in particular through the use of modern educational platforms, qualitative methodological filling of web resources, introduction of the system of quality control of distance learning in order to meet the challenges of time.

Key words: distance education; pediatrics; undergraduate training.

Вступ. Дистанційне навчання не лише активно використовується в сучасному світі, наприклад, відома Global Distance Education Network (GDENET), але й розвивається [4]. Положення про дистанційне навчання затверджено наказом Міністерства освіти і науки України від 25.04.2013 р. № 466,

(ㄷ О. П. Волосовець, О. В. Виговська, С. П. Кривопустов та ін. що зареєстровано в Міністерстві юстиції України 30.04.2013 р. за № 703/23235. Виклики сьогодення щодо попередження поширення коронавірусної інфекції COVID-19, з огляду на необхідність забезпечення протиепідемічних заходів, надзвичайно актуалізують цю форму навчання та ії вдосконалення у вищій медичній освіті [1]. Наше завдання 
не тільки надати студентам необхідний обсяг навчального матеріалу, але й моніторувати їх успішність увесь період карантину.

Відповідно до наказу МОН України від 25.04.2013 р. № 466, під дистанційним навчанням розуміється індивідуалізований процес набуття знань, умінь, навичок і способів пізнавальної діяльності людини, який відбувається в основному за опосередкованої взаємодії віддалених один від одного учасників навчального процесу у спеціалізованому середовищі, яке функціонує на базі сучасних психолого-педагогічних та інформаційнокомунікаційних технологій [2].

Переведення науково-педагогічних працівників НМУ на дистанційний режим роботи відбулося відповідно до розпоряджень та листа МОН України від 11.03.2020 р. № 1/9-154.

Згідно з наказом НМУ від 18.03.2020 р. № 160 «Про затвердження Положення про дистанційне навчання Національного медичного університету імені О. О. Богомольця», були визначені особливості застосування положень чинного законодавства до запровадження такої форми навчання в НМУ в умовах карантину через поширення коронавірусної інфекції в Україні [3].

Мета статті - визначити шляхи щодо створення системи викладання за дистанційною формою навчання на кафедрі педіатрії № 2 Національного медичного університету імені О. О. Богомольця в умовах поширення коронавірусної інфекції в Україні.

Теоретична частина. Дистанційне навчання через освітню дистанційну платформу NMU Neuron у нинішній ситуації може стати дієвою складовою освітнього процесу, маючи при цьому низку переваг. Воно не лише забезпечує навчання студента у найбільш зручному місці та часі, доступ до електронних баз знань, але й суттєво підвищує його активну роль у самому процесі самостійного навчання, зокрема й під час вимушеного внаслідок карантину, а від викладача вимагає вдосконалення викладання як за змістом, так і за його формою.

Без сумніву, зміст дистанційного навчання має відповідати необхідному освітньо-кваліфікаційному рівню та спеціальності, у нашому випадку рівням «Спеціаліст» і «Магістр» за спеціальностями «Лікувальна справа» та «Медицина» відповідно до державних стандартів освіти й існуючих затверджених навчальних планів та програм викладання педіатрії на різних курсах. Хоча дистанційна освіта і більшість існуючих освітніх платформ більше спрямовані, на нашу думку, до теоретичних навчальних дисциплін, ніж до клінічних.

Основними видами занять за дистанційною формою навчання є традиційні форми освітньої підготовки: лекція, практичні заняття, семінар, лабораторні заняття, консультації та інші, що відповідають чинному законодавству.

За допомогою платформи Neuron у Національному медичному університеті імені О. О. Богомольця вже проводяться підготовка студентів до ЄДКІ та KPOK 2 для усіх факультетів залежно від змісту іспиту та післядипломна підготовка в інтернатурі.

Обліково-звітні форми, затверджені наказом Національного медичного університету імені О. О. Богомольця (далі - НМУ) від 30.08.2016 р. № 544, заповнюються $з$ приміткою - дистанційна форма навчання (платформа Neuron).

Дуже важливо, що виконання навчального навантаження кафедри за дистанційною формою навчання має повністю відповідати запланованому навантаженню кафедр. Учасниками навчального процесу, що відбувається за дистанційною формою навчання, є студенти, викладачі та, бажано, спеціалісти інформаційних технологій або адміністратори дистанційного навчання.

Самостійне навчання передбачає поширення необхідного освітнього контенту для проведення практичних занять і лекцій, що студенти можуть отримувати через Інтернет за допомогою й інших освітніх платформ для самостійного оволодіння навчальним матеріалом (Prometheus, Coursera, eDX, EdEra та KhanAcademy тощо).

Необхідні книги студент та викладач у процесі дистанційного навчання за потреби може замовити у бібліотеці НМУ, заповнивши он-лайн заявку установленої форми, що надсилається на е-пошту: library@nmu.ua.

Звичайно, що заклад вищої освіти може створювати власний веб-ресурс із відповідним доступом для суб’єктів навчання. Наша кафедра може створювати і власну інформаційну базу, вебсередовище дистанційного навчання як сукупність веб-ресурсів, використовувати свій веб-сайт, інтернет-сторінки з наявними відеофайлами та іншими інформаційними джерелами, зокрема створеними y Facebook.

Наш весняний досвід карантину підтвердив ефективність цієї форми навчання, коли на початку перерви у заняттях кафедрою педіатрії № 2 оперативно за допомогою деканатів НМУ були зібрані 
всі необхідні контакти щодо суб’єктів навчання, передусім старост навчальних груп.

За умови присутності всіх студентів у Facebook можливо створити закриту або відкриту навчальну групу для можливого ведення трансляцій лекцій або практичних занять тощо. На жаль, виші та викладачі фінансово обмежені щодо застосування більш потужних освітніх ресурсів, як, наприклад, SMLS. Але тут до кожної лекції чи практичного заняття можна додати необхідний навчальний матеріал та рекомендації, що автоматично обумовлює його отримання студентом у своєму обліковому записі разом з оцінками та коментарями викладача. Можливий і зворотний процес спілкування, відгуки та побажання щодо проведення заняття.

Наша кафедра була готова до такої форми реалізації навчального процесу, адже робочим навчальним планом із педіатричних спеціальностей передбачена третина навчального часу на оволодіння необхідним освітнім контентом шляхом самостійної роботи.

Важливо перед початком дистанційного курсу визначитися 3 кожною студентською групою або курсом щодо методів викладання та контролю і процесу оцінювання. Після виконання необхідного завдання студенти обов'язково мають отримати зворотний зв'язок із викладачем задля обговорення.

Так, лекції можуть бути з трансляцією або надаватися як відео в записаному вигляді, або у вигляді презентацій. Доцільною є візуальна та звукова демонстрація матеріалу, що вивчається: це, наприклад, жовтяниця новонароджених, свистяче дихання, кардіальні шуми, демонстрація сучасних методів інструментального дослідження тощо. Надання студентам спрямованого навчального матеріалу не має бути обмеженим методичною розробкою 3 текстовою та графічною інформацією, а повинно мати різні посилання на відкриті веб-ресурси, відео-, аудіофайли, i, дуже важливо, гіперпосилання задля більш поглибленого вивчення проблеми та вдосконалення здатності вчитися, самостійно знаходити й аналізувати сучасну інформацію.

Поруч із цим, задля навчання в дистанційному режимі раціонально використовувати наявні відео- та інші матеріали, що доступні в мережі «Інтернет» у відкритому доступі, клінічні рекомендації та інші навчальні матеріали провідних освітніх установ світу. При цьому веб-ресурси, що використовуються, мають бути обговорені та затверджені на методичній нараді кафедри, методичних комісіях, зазначені в робочих програмах тощо. Яскравий прик- лад - наявні ресурси ВООЗ/ЮНІСЕФ з Integrated Management of Childhood Illness (IMCI) для роботи студентів 6-го курсу та інтернів з педіатрії.

Практичні заняття повинні мати можливість використання засобів симуляційного навчання, як приклад, віртуальних тренажерів, зокрема, відома технологія створення віртуального класу. Під час практичних занять 3 педіатрії, особливо на 6-му курсі, дистанційне навчання доцільно поєднувати 3 можливостями телемедицини і здійсненням консультацій, консиліумів пацієнтів педіатричного профілю.

Зворотний зв'язок із викладачем надзвичайно важливий - від обговорення результатів виконання тестових завдань, ситуаційних задач за допомогою електронної пошти до вільного спілкування під час відеолекції, телеконференції, в чаті, соціальних мережах. Доцільно намагатися здійснювати діалог, а за можливості - дискусію з усіма учасниками освітнього процесу. Зараз вивчаються та впроваджуються психолого-педагогічні технології дистанційного навчання.

Крім лекцій, семінарів, важлива увага має надаватися самостійній роботі студентів, при цьому доцільно використовувати наявний на кафедрі банк тестів, завдань, робочі зошити, дані лабораторних та інструментальних методів обстеження, електронні бібліотеки, навчальні відеофільми тощо. До самостійної роботи також відноситься підготовка рефератів, у тому числі $з$ розглядом рідкісних клінічних випадків. Окремий напрямок дистанційного навчання - консультації студентів, як поточні, так і перед підсумковим контролем із можливістю пробного виконання контрольних завдань.

Підсумковий контроль знань теж проводиться за допомогою дистанційних технологій, при цьому надзвичайно актуальним стає відеозв'язок як інформаційно-комунікаційна технологія, що надає можливість забезпечення аутентифікації того, хто навчається. В іншому випадку - цей контроль здійснюється очно.

Висновок. У цілому, технології дистанційного навчання як комплекс сучасних освітніх технологій у системі вищої медичної освіти має постійно вдосконалюватися, зокрема шляхом використання сучасних освітніх платформ, якісного методичного наповнення веб-ресурсів, запровадження системи контролю якості дистанційного навчання, аби відповідати викликам часу. 


\section{Список літератури}

1. Про запобігання поширенню на території України коронавірусу COVID-19 : Постанова Кабінету Міністрів України від 11 березня 2020 р. № 211.

2. Про затвердження Положення про дистанційне навчання : наказ Міністерства освіти і науки України від 25.04.2013 р. № 466.

\section{References}

1. Pro zapobihannia poshyrenniu na terytorii Ukrainy koronavirusu COVID-19 [On prevention of the spread of COVID-19 coronavirus on the territory of Ukraine]. Postanova Kabinetu Ministriv Ukrainy vid 11 bereznia 2020 r. № 211 - Resolution of the Cabinet of Ministers of Ukraine of March 11, 2020 No. 211 [in Ukrainian].

2. Pro zatverdzhennia Polozhennia pro dystantsiine navchannia [On approval of the Regulations on distance learning]. Nakaz Ministerstva osvity i nauky Ukrainy vid 25.04.2013 r. № 466 - Order of the Ministry of Education and Science of Ukraine dated 25.04.2013 No. 466 [in Ukrainian].

Електронна адреса для листування: volosovec@ukr.net
3. Про затвердження Положення про дистанційне навчання Національного медичного університету імені О. О. Богомольця : наказ НМУ від 18.03.2020 р. № 160.

4. Distance Education. - Access mode : https://www. tandfonline.com/toc/cdie20/current.

3. Pro zatverdzhennia Polozhennia pro dystantsiine navchannia Natsionalnoho medychnoho universytetu imeni O.O. Bohomoltsia [On approval of the Regulations on distance learning of the National Medical University named after O.O. Bohomolets]. Nakaz NMU vid 18.03.2020 r. № 160 - Resolution of the NMU of 18.03.2020, No. 160 [in Ukrainian].

4. Distance Education. Retrieved from: https://www.tandfonline.com/toc/cdie20/current. 